\title{
The Semantic Differences of English and Chinese "地” from the Perspective of Functional Equivalence and Translation Teaching Strategies
}

Chu Yan*, Shi Longfeng

English Department, Foreign Language School, North China Electric Power University, Baoding, Hebei, China

\author{
DOI: $10.36348 /$ sijll.2021.v04i02.003
}

| Received: 12.01.2021 | Accepted: 23.01.2021 | Published: 09.02.2021

*Corresponding author: Chu Yan

\section{Abstract}

Different nations and different environments have led to huge differences between cultures, forming different forms of cultural models. In the process of English-Chinese translation, in order to ensure the accuracy and correspondence of translation, translators tend to follow Nida's functional equivalence theory. This theory advocates formal equivalence and emphasizes dynamic equivalence. In practical translation application, functional equivalence theory is of guiding significance to English-Chinese translation. In terms of language, the same meaning is expressed differently in different cultures. “地”has different semantic meanings in English and Chinese. This article will discuss the different semantic meanings of the differences and similarities between Chinese and English by comparing the difference between “地” in Chinese and English idioms and poems. The differences in the characteristics of Chinese and English languages mainly come from the following factors: the influence of geographical environment and lifestyle, the restriction of religious belief, and the differences in thinking modes.

Keywords: semantic meanings; functional equivalence theory; cultural difference; cultural similarity.

Copyright (0) 2021 The Author(s): This is an open-access article distributed under the terms of the Creative Commons Attribution 4.0 International License (CC BY-NC 4.0) which permits unrestricted use, distribution, and reproduction in any medium for non-commercial use provided the original author and source are credited.

\section{INTRODUCTION}

Belonging to different language families, English and Chinese are different in many ways. One display of such differences is lexical disparity, or lexical gap, which causes much difficulty in translation between the two languages [1]. Zhou Fangzhu put forward the concept of "gaps in translation", which includes "semantic gap". Lexical gap is an issue requiring emphasis in translation, but we hold that gaps in translation concern not just the lexical level but also the levels of phrases and sentences [2]. We use the term "lexeme gap" to refer to what is usually called "lexical gap", which should include "semantic gap" or "meaning gap" (the gap caused by the fact that the socalled corresponding words between the two languages do not share all of the same meanings), and "usage gap" (the gap caused by different usages of the so-called corresponding words between the two languages) [3].

The "lexical gap", a synonymous word or phrase-sometimes even a clause-could be used in order to convey the intended meaning in the target language, is what we shall discuss in this essay. It will analyze what causes the semantic gap at the lexical level vis-a- vis the motivation of the origin of words and the cognitive aspect [4]

\section{Common, Metaphorical and Extended Meanings in Chinese}

The word “地” has different meanings in different cultures and situations. The following content will be specific about different common, metaphorical and extended meanings of “地” in Chinese [5].

\section{Four-Character Idioms}

Firstly, through studying the different meanings of “地” in Chinese idiom website, it is found that "地” has the following different meanings: common meaning, metaphorical meaning and extended meaning [6].

\section{Common Meaning}

The most common meaning of “地” can be expressed by "land, space" in Chinese: Land not suitable for cattle and horses, that is the wasteland-不牧 之地 in Chinese; No grain is produced. Land that cannot be cultivated-不食之地 in Chinese; The meaning might be vast territory and abundant resources-地大物博 in Chinese; Land is vast and 
Chu Yan \& Shi Longfeng., Sch Int J Linguist Lit, Feb, 2021; 4(2): 48-52

sparsely populated-地广人稀 in Chinese; It refers to a tiny area, that is the place are very narrow-弹丸之地 in Chinese; The meaning is a hotly contested spot, that is a battleground- 必争之地 in Chinese; The original meaning was that those who are good at fighting have the confidence to win, and will not fall into a setback不败之地 in Chinese; There is a place where no vegetation crops grow, that is desolate and barren-不毛 之地 in Chinese; It refers to Infertile land and poor people-地痊民贫 in Chinese; A glory place propitious for giving birth to outstanding men-地灵人杰 in Chinese; One can't adapt to the climatic conditions or eating habits of a place-不习地土 in Chinese; It refers to living or living in a certain place, or to use a certain place as the foundation of construction-安身之地 in Chinese [7].

Through the comparative analysis of the above specific cases, it is found that the common meaning of " 地" in the context of Chinese idioms is mostly "land, space", which can be translated into "land, territory, area, place, spot" in most cases in English.

\section{Metaphorical Meaning}

In addition to the common meaning of “地” in the poem, in the poem, this essay also discusses the metaphorical meaning. Metaphorically “地” may have several kinds of meaning: One is certain to win and has the advantage that it will not fail, that is an invincible position-不败之地 in Chinese; Something is blooming everywhere or spring up all over the country-遍地开花 in Chinese; It refers to remove obtrusive things for the sake of convenience or crowd out others in order to expand the site-拢了夢卜地皮宽 in Chinese.; It's a metaphorical meaning that's a guilty person conspicuously protests his innocence-此地无银三百两 in Chinese; The meaning is a harsh environment with thorns everywhere-地棘天荆 in Chinese; It refers to prosperous social life-地上天官 in Chinese; It refers to the closing circle set up and down, that's close encirclement of enemies, fugitives, etc.-地网天罗 in Chinese; It means the dark and cruel of society-地狱变 相 in Chinese; The metaphorical meaning is to settle down in the long-term or to do a good job with all your heart and soul, that's a bryophyllum-落地生根 in Chinese; Metaphorically, Buddhists persuade evildoers to recognize their crimes, and resolve to change and become good people-放下屠刀, 立地成佛 in Chinese [8].

Through the comparative analysis of the above specific cases, it is found that the metaphorical meaning of “地” in the context of Chinese idioms may be translated into "position, everywhere, site, environment, social life, society, bryophyllum". There may also have other meanings, which will be further studied in the future.

\section{Extended Meaning}

Lastly, as for the extended meaning of “地”, it has so many different meaning, which is derived from its basic meaning "earth or land"; It means have an exaggerated opinion of one's abilities, that's arrogance不知天高地厚 in Chinese; One is north of the earth, one is south of the sky, that's the areas vary or far away-地北天南、地角天涯 in Chinese; It describes something everlasting and unchanging-地久天长 in Chinese; It refers to the courtesy of the host on the reception-地主之谊 in Chinese; The conditions in terms of geographical environment and personnel relations are favorable-地利人和 in Chinese; Something is the age of earth and the extent of heaven地老天荒 in Chinese; The body is burly, the image is tall, and the spirit is magnificent-顶天立地 in Chinese; The meaning is do not go to extremes in speaking and doing things, leaving room for maneuver and flexibility-留有余地 in Chinese; It seems that spring is back to the earth, that's the severe cold is over, warmth and vitality come to earth again-春回大地 in Chinese; One is too old to die at any time-旦暮入地 in Chinese.

Specific case through the above analysis, it is found that the "地" in Chinese idioms in the context of metaphorical and extended meaning derived much from the original intention. There maybe a bit philosophical meaning in it, but still remains to be proven.

\section{In Poems}

As for the above several meanings of “地”, it found their differences Chinese idiom network. Next, we will study and discuss whether “地” also contains the above meanings in Chinese ancient poetry and prose network. As for poems, the Chinese word “地”, which have different meanings: common meaning, and metaphorical meaning.

\section{Common Meaning}

Such as 问君何能尔, 心远地自偏(Ask me why I can do this, as long as my heart is high, I will naturally feel that the place is quiet.). 巴山楚水凄凉地 ，二十三年弃置身(Degraded to the desolate areas of Bashan Chushui, spent 23 years of decline.). 床前明月 光, 疑是地上霜 (Bright moonlight spilled on the window paper, as if a layer of frost had appeared on the ground.). 在天愿作比翼鸟, 在地愿为连理枝(In the sky is willing to be a double-winged bird, and in the ground is willing to co-exist with branches.). 碧云天,

黄叶地(The sky is blue and blue with yellow leaves all over the ground.). 天地合, 乃敢与君绝(Heaven and earth meet and converge, and I dare to abandon my affection for you!). 北风卷地白草折，胡天八月即飞 雪(The north wind swept the earth and blown the white grass, and the sky in Saibei fell heavy snow in August.). 念天地之悠悠, 独怆然而涕下(I can't help crying 
Chu Yan \& Shi Longfeng., Sch Int J Linguist Lit, Feb, 2021; 4(2): 48-52

with sorrow and tears when I think of only the vast world.). 雪尽天地明, 风开湖山貌(During the day, the sky and the earth are bright like snow, and the breeze slowly comes back to the mountains).

Through the above examples, we found that the common meanings of "地” can be expressed as "place, areas, ground, earth, world".

\section{Metaphorical Meaning}

Next, we will discuss the metaphorical meanings of “地”. Such as 渔阳韾鼓动地来, 惊破霓 裳羽衣曲(The drums of war in the Yuyang rebellion are deafening, and the palace stops playing the plume feathers.). 天长地久有时尽, 此恨绵绵无绝期(There will always be an end, even if it is forever, but the life and death hate never ends.). 天旋地转回龙驭, 到此踌 躇不能去 (The situation improved, the emperor returned to Chang'an, passing by Ma Yipo and seeing people thinking about lingering).

Through the above examples, we found that the common meanings of “地” can be expressed as "place, situation".

\section{Common, Metaphorical and Extended meanings of “地” in English}

The relevant meaning of “地” in English can be: earth, land, fields, ground, floor, place, site, position, situation, background, distance, etc., but in addition to these meanings of each word itself, it also has many metaphorical and extended meanings.

\section{In Four-character Idioms}

By looking up Concise English-Chinese Idioms Dictionary, in Four-character Idioms, the relevant meaning about “地” may be "earth, land ground, place" , that is common and Extended meanings. As following: Be down-to-earth (in Chinese “脚踏实地”); To fail to build a mound for want of one final basket of earth( (in Chinese “功亏一簤”); Land a/one's fish (in Chinese “把鱼钓上岸, 即马到成功 ”); Land all over someone (in Chinese “抨击某人”); Land flowing with milk and honey (in Chinese “英雄 的乐土”); Land in one's hand (in Chinese “使落入某 人手中”); Land in a tight spot (in Chinese “使某人处 于困境”); Land like a cat (in Chinese “幸运脱险, 免 遭伤害”); Land on one's feet (in Chinese “逢凶化吉, 化险为夷”); Land on the street level (in Chinese “处 于失业中”); Land-office business (in Chinese “极好 的主意”); Ground oneself in something (in Chinese “ 自学”); Ground sliding from one' feet (in Chinese “地 位不稳”); Place in the shoes of another person (in Chinese “代替别人的位置”); Place in the sun (in Chinese “有发展前途的地位”); Place oneself on record (in Chinese “出类拔萃/许下诺言”).
Through the above example, we found that the “地” in the English idiom is more beyond the meaning of the word itself, have more Metaphorical and Extended meanings that described the target becomes more vivid and image.

\section{Classical Poetry Works}

In addition to the relevant meanings “地”, through the research we found that in English poems “地” has more common meaning, such as “地球、大地、郊原”.

A. Beautiful Earth more beautiful, with flowers and trees missed.

B. The loud voice is famous to silence, which knew it would inherit the earth, before anybody said so. Make the earth your companion.

C. Search where you may, You will not find a land. As beautiful as this, She is the queen of all lands, This land of my birth, My motherland.

D. The golden sea its mirror spreads. Beneath the golden skies, And but a narrow strip between of land and shadow lies.

E. White daisies prank the ground.

Through the above examples, we found that " 地” gets more common meaning- “地球” in Chinese. In English poetry, the image is more specific, and the objects described are more reductive, giving people the feeling of immersive.

\section{The Relationships between Chinese and English}

“地” may be “土地、地盘、地方” in Chinese and may be "earth, land, ground, place, land, territory, area, place, spot" in English. Meanwhile, it reflects that the differences in thinking mode, that is essentially a cultural difference which is the difference and similarity between Chinese and English cultures.

\section{The Differences between Chinese and English}

Because of the differences between Chinese and western cultural traditions, the preference for image thinking and abstract thinking is also different.

\section{Cultural patterns determine the way of thinking}

Different nations live in a specific natural geographical environment, forming their own historical background and cultural traditions, thus forming their own mode of thinking. With the development of natural science, western culture characterized by analytical thinking, which is different from Chinese culture, has clearly distinguished between subject and object, man and nature, spirit and matter, thinking and existence, soul and body, phenomenon and essence. This "opposition" is clearly different from the "unity" that the Chinese prefer. Therefore, on the whole, the differences between Chinese and western cultural patterns determine the differences in the way of 
Chu Yan \& Shi Longfeng., Sch Int J Linguist Lit, Feb, 2021; 4(2): 48-52

thinking. For example, Chinese people lay stress on humanities and ethics, while westerners lay stress on nature and science and technology. Chinese people value perception, intuition and image, while westerners value reason, logic and demonstration. The Chinese are quiet, conservative, seeking stability and harmony, while the westerners are active, open, seeking differences and emphasizing competition.

\section{Cultural differences are manifested as thinking differences}

The mode of thinking varies from person to person, and the difference of thinking due to cultural background is more obvious. People are used to thinking and understanding things in their own culture. The mainstream spirit of traditional Chinese culture is the practical rational spirit, that is, the overall world view of "the unity of heaven and man", while the mainstream spirit of western culture is the speculative rational spirit, that is, the world is constituted by the most abstract units and laws, so as to form the reasoning method of thinking and obtain the cognition of the world. Chinese people prefer synthesis, British and American people prefer analysis, which leads to the overall priority of thinking, while preference analysis leads to the feature of partial priority of thinking.

\section{The Similarities between Chinese and English}

From the perspective of Chinese and western poetry and idiom comparison can be seen in humanistic thoughts, philosophical views, emotional expression, the use of metaphor and other aspects of the similarities between Chinese and western cultural thinking. From the perspective of the translation of the word "地" in the context of Chinese and English culture, the similarity between Chinese and English culture is mainly reflected in the similarity of humanistic thought and value orientation. Humanistic thoughts emphasize the value of human, the meaning of human existence, and strive to promote human nature and advocate human freedom. No matter what society will reflect the importance of humanities. And values are also set up in the long-term development of the society. In these aspects, although there are many differences between Chinese and western cultures and regions are far apart, some of the most essential things of human beings are interlinked. In the above translation of “地” in Chinese and English idioms and poems, we find that these idioms emphasize the development of human nature and advocate human freedom. Although the western humanistic thoughts advocate breaking the rule of theology and separating the rule of god over man, while the eastern humanistic thoughts advocate the combination of man and the way of heaven, some similarities between Chinese and western humanistic thoughts can be seen from the translation of poems and idioms.

\section{CONCLUSION AND IMPLICATION}

In the process of English-Chinese translation, only by fully following the principle of functional equivalence, can we truly ensure the original, accurate and unobstructed translation of sentences, and make the article still full of brilliance under the language conversion. Therefore, translators must take functional equivalence as the basic translation criterion, respect different language and cultural environments, and improve the level of translation. From these examples, we can come to the conclusion that there is a basis for the generation of meanings in the category of word meaning, and there is often a certain connection between the new and old meanings. A word is a polysemous category composed of several superficially different meanings. These seemingly unrelated meanings are connected through "meaning chains". There are some common features or other similarities between them, resulting in the relationship between them. The meaning constantly appears, develops, enriches and extends, thus forming the category of "family resemblance" and producing the polysemy of semantic category.

It is very useful for our English teaching to understand the polysemy of a word in semantic category. It can help us guide students to draw inferences from one instance, learn English flexibly and easily, and master English Polysemy skillfully. In the aspect of English Chinese translation teaching, it can help us to guide students to learn "choice of words" (i.e. wording, such as when an English word appears, which Chinese word should be used), so as to improve the skills of English translation. From these examples, we can come to the conclusion that there is a basis for the generation of meanings in the category of word meaning, and there is often a certain connection between the new and old meanings. A word is a polysemous category composed of several superficially different meanings. These seemingly unrelated meanings are connected through "meaning chains". There are some common features or other similarities between them, resulting in the relationship between them. The meaning constantly appears, develops, enriches and extends, thus forming the category of "family resemblance" and producing the polysemy of semantic category.

\section{REFERENCES}

1. Chen, W. (2005). Dictionary of English proverbs and idioms [M]. Beijing: World Knowledge Press, 356.

2. Fang, F. (2016). Influence of Cultural Differences on Translation [J]. Overseas English. (23).

3. $\mathrm{Xu}$, J. (2019). A Comparative Study of the Translation of English and Chinese idioms [J]. Campus English. (30).

4. Wittgenstein. (1953). Philosophical Investigation [M]. Oxford: Basil Blackwell.

5. Wang, F., \& Cai, J. (2001). 500 sentences of 
Chu Yan \& Shi Longfeng., Sch Int J Linguist Lit, Feb, 2021; 4(2): 48-52

English proverbs [M]. Beijing: Foreign Language Press, 69.

6. Wen, D. (2004). A complete collection of Chinese proverbs [M]. Shanghai: Shanghai Translation Publishing House, 246.

7. Wang, D., Yang, S., \& Huang, Y. (2003). Chinese
English proverbs and culture [M]. Shanghai:

Shanghai Foreign Language Education Press; 103.

8. Zhang, F. (1984). Oxford modern advanced English Chinese Dictionary [M]. Hong Kong: Oxford University Press. 